\title{
HUBUNGAN PENGETAHUAN PASIEN TERHADAP RASIONALITAS SWAMEDIKASI DI BEBERAPA APOTEK KECAMATAN LUBUK BASUNG
}

\author{
Zulkarni $\mathrm{R}^{1}$, Rahmi Yosmar ${ }^{2}$, Intan Octafiani ${ }^{1}$ \\ ${ }^{1}$ Sekolah Tinggi Farmasi Indonesia, Farmasi, Padang, Indonesia \\ 2Universitas Andalas, Farmasi, Padang, Indonesia \\ apotekerkesmas@yahoo.com,rahmiyosmar@gmail.com,octafiani@gmail.com
}

\begin{abstract}
Self-medication (self-medication) one's efforts to treat symptoms of illness or disease without consulting a doctor first. Treatment itself can be a source of drug-related problems (Drug related Problems) due to limited knowledge about drugs and their use. The purpose of this study was to determine the relationship of knowledge to self-medication rationality. This study uses a cross sectional method. 193 respondents from three pharmacies involved in this study. Respondents aged 23-60 years and above were selected by purposive sampling method. Data retrieval is done through filling out questionnaires that have been tested for validity and reliability. Data were analyzed by Chi-square test using Statistical Product and Server Solution (SPSS) version 23. The results showed that the patient's knowledge level of $43.0 \%$ was classified as good, $38.3 \%$ was moderate, $18.7 \%$ was classified as poor. The use of self-medication is $77.2 \%$ rational and $22.8 \%$ is irrational. Based on Chi-square results, the level of knowledge is influenced by age, gender and occupation. While self-administered rationality is influenced by recent education. There is no relationship to knowledge and self-rationality. Based on the results of this study it was found that the majority of the patient's level of knowledge was classified as good. The use of irrational medicinal drugs reaches $22.8 \%$.
\end{abstract}

Key words : Self-medication, Drug Related Problems, Knowledge, Rationality

\begin{abstract}
Abstrak
Pengobatan sendiri (swamedikasi) upaya seseorang mengobati gejala sakit atau penyakit tanpa berkonsultasi dengan dokter terlebih dahulu. Pengobatan sendiri dapat menjadi sumber masalah terkait obat (Drug related Problem) akibat terbatasnya pengetahuan mengenai obat dan penggunaannya. Tujuan penelitian ini adalah untuk mengetahui hubungan pengetahuan terhadap rasionalitas swamedikasi. Penelitian ini menggunaan metode cross sectional. Sebanyak 193 responden dari tiga apotek yang terlibat dalam penelitian ini. Responden berusia 23- 60 tahun keatas dipilih dengan metode purposive sampling. Pengambilan data dilakukan melalui pengisian kuesioner yang telah diuji validitas dan reliabilitasnya. Data dianalisis dengan uji Chi-square menggunakan Statistical Product and Server Solution (SPSS) versi 23. Hasil penelitian menunjukkan bahwa tingkat pengetahuan pasien $43.0 \%$ tergolong baik, $38.3 \%$ tergolong sedang, $18.7 \%$ tergolong buruk. Penggunaan obat swamedikasi $77.2 \%$ rasional dan $22.8 \%$ tidak rasional. Berdasarkan hasil Chi-square, tingkat pengetahuan dipengaruhi usia, jenis kelamin dan pekerjaan. Sedangkan rasionalitas swamedikasi dipengaruhi oleh pendidikan terakhir. Tidak terdapat hubungan
\end{abstract}


terhadap pengetahuan dan rasionalitas swamedikasi. Berdasarkan hasil penelitian ini diperoleh bahwa mayoritas tingkat pengetahuan pasien tergolong baik. Penggunaan obat swamedikasi yang tidak rasional mencapai $22.8 \%$.

Kata kunci : Swamedikasi, Drug Related Problem, Pengetahuan, Rasionalitas

\section{PENDAHULUAN}

Swamedikasi menurut World Health Organization (WHO) adalah pemilihan obat modern, herbal, maupun obat tradisional oleh seorang individu untuk mengatasi penyakit atau gejala penyakit, terdapat sebanyak $80 \%$ masyarakat dibeberapa negara melakukan swamedikasi (WHO, 1998).

Menurut Permenkes No. 99/MENKES/PER/1993, secara sederhana swamedikasi adalah upaya seseorang mengobati gejala sakit atau penyakit tanpa berkonsultasi dengan dokter terlebih dahulu. Swamedikasi boleh dilakukan untuk kondisi penyakit yang ringan, umum dan tidak akut (Depkes, RI 2011).

Sesuai dengan data Riset Dasar Kesehatan Nasional Tahun 2013, Sejumlah 103.860 atau 35,2 persen dari 294.959 rumah tangga di Indonesia menyimpan obat untuk swamedikasi, dengan proporsi tertinggi rumah tangga di DKI Jakarta $(56,4 \%)$ dan terendah di Nusa Tenggara Timur $(17,2 \%)$. Rerata sediaan obat yang disimpan hampir 3 macam. Dari 35,2 persen RT yang menyimpan obat, proporsi rumah tangga yang menyimpan obat keras 35,7 persen dan antibiotika 27,8 persen. Adanya obat keras dan antibiotika untuk swamedikasi menunjukkan penggunaan obat yang tidak rasional. Terdapat 81,9 persen rumah tangga menyimpan obat keras dan 86,1 persen rumah tangga menyimpan antibiotika yang diperoleh tanpa resep (Riskesdas, 2013).

Berdasarkan data dari Badan Pusat Statistik (BPS) mencatat bahwa terdapat 79,49\% di Kabupaten Agam, 80,04\% di Sumatera Barat dan 90,54\% di Indonesia orang sakit melakukan swamedikasi. Angka ini lebih tinggi dibandingkan persentase penduduk yang berobat jalan ke dokter yakni sebesar 34\% (BPS, 2018).

Sampai saat ini di tengah masyarakat seringkali dijumpai berbagai masalah dalam penggunaan obat. Diantaranya ialah kurangnya pemahaman tentang penggunaan obat tepat dan rasional, penggunaan obat bebas secara berlebihan, serta kurangnya pemahaman tentang cara menyimpan dan membuang obat 
dengan benar. Sedangkan tenaga kesehatan masih dirasakan kurang memberikan informasi yang memadai tentang penggunaan obat (Depkes RI, 2014). Oleh karena itu, sebagai pelaku self-medication harus mampu mengetahui jenis obat yang diperlukan, kegunaan dari tiap obat, menggunakan obat dengan benar (cara, aturan pakai, lama pemakaian), mengetahui efek samping obat yang digunakan dan siapa yang tidak boleh menggunakan obat tersebut (Depkes RI, 2008).

Berdasarkan latar belakang di atas serta belum ada penelitian mengenai hubungan pengetahuan masyarakat terhadap rasionalitas swamedikasi di Kecamatan Lubuk Basung, maka peneliti tertarik untuk melakukan penelitian tersebut dengan harapan dapat memberikan gambaran mengenai kondisi swamedikasi pada sebagian besar masyarakat Kecamatan Lubuk Basung.

\section{METODE PENELITIAN}

Penelitian ini merupakan penelitian deskriptif, dengan model penelitian survei yang menggunakan pendekatan cross sectional (Swarjana, 2012). Mendeskripsikan secara faktual, akurat dan sistematis mengenai pengetahuan pasien terhadap swamedikasi di beberapa Apotek di Kecamatan Lubuk Basung. Populasi dalam penelitian ini adalah seluruh pasien swamedikasi yang berusia lebih dari usia 23 tahun keatas yang berlangsung pada Apotek di Kecamatan Lubuk Basung. Berdasarkan hasil survei awal jumlah pasien swamedikasi perbulan pada Apotek A didapat \pm 140 orang, Apotek B didapat \pm 235 , dan Apotek $C$ didapat \pm 185 orang yang berkunjung ke Apotek.Sampel dalam penelitian ini di hitung berdasarkan rumus slovin dengan taraf kepercayaan $90 \%$ $(\alpha=10 \%)$. Berdasarkan perhitungan dengan Rumus Slovin ini pada Apotek $A$ adalah 58 orang, Apotek B adalah70 orang,dan pada Apotek C 65 orang. Subjek penelitian ini dipilih berdasarkan metode purposive sampling, dengan menetapkan kriteria inklusi dan ekslusi.

Instrumen penelitian yang digunakan pada penelitian ini adalah kuesioner yang dimodifikasi dari beberapa penelitian sebelumnya. kuesioner yang digunakan terdiri dari 2 bagian yaitu kuesioner bagian I, berupa pertanyaan tentang demografi. Pertanyaan tersebut mengenai usia, jenis kelamin, pekerjaan, jumlah penghasilan. Kuesioner bagian II, berupa pertanyaan tentang apakah pasien pernah menggunakan obat swamedikasi, dimana mengetahui pengetahuan pasien tentang swamedikasi dan rasionalitas swamedikasi. 
Sebelum digunakan kuesioner dilakukan uji validitas dan reliabilitas. Uji validitas dilakukan dengan Korelasi Pearson Product Moment, dengan melakukan pilot study pada 30 orang responden, sedangkan uji reliabilitas dilakukan pada pernyataan yang telah valid menggunakaan teknik cronbach alpha.

Izin penelitiaan diajukan ke Apotek, sedangkan uji etik diajukan ke Komisi etik Penelitian Kesehatan Fakultas Kedokteran Universitas Andalas. Pengumpulan data data dilakukan selama periode Desember 2018-Februari 2019. Responden diberikan tiga jenis dokumen saat pengambilan data, yaitu surat yang menjelaskan gambaran dan tujuan dalam penelitian, lembar persetujiaan keikutsertaan dalam penelitian (informent consent), dan kuesioner. Hubungan pengetahuan dengan rasionalitas swamedikasi dianalisis secara bivariat menggunakan Chi-Square Test.

\section{HASIL DAN PEMBAHASAN}

\section{Karakteristik Responden}

Sebanyak 193 responden yang terlibat dalam penelitian ini, 58 responden berasal dari apotek $A, 70$ responden berasal dari apotek $B, 65$ responden berasal dari apotek $\mathrm{C}$. Berdasarkan hasil penelitian ini didominasi oleh perempuan (58\%), sedangkan golongan umur didominasi responden dengan umur 31- 40 tahun (27.5\%). Pendidikan terakhir mayoritas SMK/SMA (49.2\%) dan pekerjaan didominasi dengan ibu rumah tangga (28.5\%). Untuk penghasilan didominasi Rp.1.000.000-Rp.2.000.000,- (43.5\%).

Tabel 1. Karakteristik Responden

\begin{tabular}{|c|c|c|c|}
\hline $\mathrm{NO}$ & $\begin{array}{c}\text { KARAKTERISTIK } \\
\text { SOSIODEMOGRAFI }\end{array}$ & $\begin{array}{c}\text { JUMLAH } \\
\mathrm{N}=193\end{array}$ & $\begin{array}{c}\text { PERSENTASE } \\
\%\end{array}$ \\
\hline 1 & $\begin{array}{l}\text { Usia } \\
\text { a. 23-30 Tahun } \\
\text { b. 31-40 Tahun } \\
\text { c. 40-50 Tahun } \\
\text { d. 51-60 Tahun } \\
\text { e. }>60 \text { Tahun }\end{array}$ & $\begin{array}{l}39 \\
53 \\
51 \\
29 \\
21\end{array}$ & $\begin{array}{l}20.2 \\
27.5 \\
26.4 \\
15.0 \\
10.9\end{array}$ \\
\hline 2 & $\begin{array}{l}\text { Jenis Kelamin } \\
\text { a. laki-laki } \\
\text { b. perempuan }\end{array}$ & $\begin{array}{c}81 \\
112\end{array}$ & $\begin{array}{l}42.0 \\
58.0\end{array}$ \\
\hline
\end{tabular}




\begin{tabular}{|c|c|c|c|}
\hline 3 & $\begin{array}{l}\text { Pendidikan } \\
\text { a. SD } \\
\text { b. SMP } \\
\text { c. SMA } \\
\text { d.Perguruan Tinggi } \\
\text { e. Lain-lainnya }\end{array}$ & $\begin{array}{c}15 \\
25 \\
95 \\
57 \\
1\end{array}$ & $\begin{array}{c}7.8 \\
13.0 \\
49.2 \\
29.5 \\
0.5\end{array}$ \\
\hline 4 & $\begin{array}{l}\text { Pekerjaan } \\
\text { a. Pegawai negeri } \\
\text { b. Pegawai Swasta } \\
\text { c. Wiraswasta } \\
\text { d. Rumah Tangga } \\
\text { e. Lainnya }\end{array}$ & $\begin{array}{l}25 \\
29 \\
50 \\
55 \\
34\end{array}$ & $\begin{array}{l}13.0 \\
15.0 \\
25.9 \\
28.5 \\
17.6\end{array}$ \\
\hline 5 & $\begin{array}{l}\text { Penghasilan } \\
\text { a. }<1.000 .000 \text { bulan } \\
\text { b. }>1.000 .000-2.000 .000 \text { bulan } \\
\text { c. }>2.000 .000-3.000 .000 \text { bulan } \\
\text { d. }>3.000 .000\end{array}$ & $\begin{array}{l}26 \\
84 \\
56 \\
27\end{array}$ & $\begin{array}{l}13.5 \\
43.5 \\
29.0 \\
14.0\end{array}$ \\
\hline 6 & $\begin{array}{l}\text { Kunjungan ke apotek } 3 \text { bulan } \\
\text { terakhir } \\
\text { a. } 1 \text { kali } \\
\text { b. } 2 \text { kali } \\
\text { c. } 3 \text { kali } \\
\text { d. } 4 \text { kali } \\
\text { e. } 5 \text { kali }\end{array}$ & $\begin{array}{l}14 \\
66 \\
81 \\
14 \\
18\end{array}$ & $\begin{array}{c}7.3 \\
34.2 \\
42.0 \\
7.3 \\
9.3\end{array}$ \\
\hline 7 & $\begin{array}{l}\text { Tujuan ke Apotek } \\
\text { a. tembusan resep dokter } \\
\text { b.beli obat bebas } \\
\text { c. beli obat bebas terbatas } \\
\text { d. beli obat keras }\end{array}$ & $\begin{array}{l}- \\
89 \\
77 \\
27\end{array}$ & $\begin{array}{l}- \\
46.1 \\
39.9 \\
14.0\end{array}$ \\
\hline 8 & $\begin{array}{l}\text { Konsultasi } \\
\text { a. Apoteker } \\
\text { b. asisten apoteker }\end{array}$ & $\begin{array}{c}44 \\
149\end{array}$ & $\begin{array}{l}22.8 \\
77.2\end{array}$ \\
\hline & TOTAL & 193 & \\
\hline
\end{tabular}

Berdasarkan karakteristik umur menunjukkan bahwa golongan umur 29-39 tahun merupakan kategori umur yang paling banyak menjadi responden penelitian. Rentang umur tersebut termasuk ke dalam kategori usia prima yang idealnya telah bekerja. Oleh karena itu, obat-obat bebas lebih dipilih sebagai pengobatan untuk mengatasi penyakit ringan yang dialami di sela-sela aktivitasnya karena obat bebas mudah diperoleh (Hermawati, 2012).

Berdasarkan karakteristik jenis kelamin menunjukkan bahwa perempuan lebih cenderung melakukan swamedikasi dibandingkan laki-laki, hal ini \begin{tabular}{r|rr} 
dikarenakan lebih banyaknya pengunjung perempuan yang melakukan \\
\hline (c) (i) () & Volume 4, Nomor 2, September 2019
\end{tabular} sportasaintika.ppj.unp.ac.id 
swamedikasi dan bersedia untuk diwawancara dibandingkan pengunjung lakilaki.

Berdasarkan karakteristik pekerjaan menunjukkan bahwa ibu rumah tangga lebih banyak melakukan swamedikasi, hal ini dikarenakan ibu rumah tangga dianggap lebih mengetahui kondisi kesehatan anggota keluarganya, memiliki kepekaan yang lebih besar dalam melakukan pencarian pengobatan, serta karena umumnya tidak memiliki penghasilan sendiri kebanyakan dari mereka melakukan pengobatan sendiri sebab dianggap lebih murah dan praktis tanpa perlu ke dokter.

\section{Tingkat Pengetahuan Swamedikasi}

Tingkat pengetahuan dalam swamedikasi dalam penelitian ini tergolong baik yaitu $43 \%$. Berdasarkan tingkat pengetahuan masing-masing, responden dalam penelitian ini di bagi dalam 3 kategori yaitu kategori baik (43\%), kategori sedang(38.3\%), dan buruk (18.7\%). Data distribusi frekuensi tingkat pengetahuan seluruh responden dapat dilihat secara lengkap pada Tabel 2.

Tabel 2. Distribusi frekuensi pengetahuan responden

\begin{tabular}{|l|l|l|l|}
\hline NO & Kategori & Jumlah & Persentase (\%) \\
\hline 1 & Buruk & 36 & 18.7 \\
\hline 2 & Sedang & 74 & 38.3 \\
\hline 3 & Baik & 83 & 43.0 \\
\hline & TOTAL & 193 & 100 \\
\hline
\end{tabular}

\section{Rasionalitas Penggunaan Obat}

Berbagai kriteria telah ditetapkan untuk menentukan kerasionalan penggunaan suatu obat. Rasionalitas penggunaan obat dalam swamedikasi berdasarkan hasil penilaian mengenai rasionalitas penggunaan obat, dapat disimpulkan bahwa mayoritas responden di tiga apotek menggunakan obat secara rasional (77.2\%) dapat dilihat pada Tabel 3. Menurut WHO, penggunaan obat yang rasional merujuk pada penggunaan obat yang benar, sesuai dan tepat. Penggunaan obat di sarana pelayanan kesehatan umum nya belum rasional. Oleh karena itu, diperlukan adanya promosi penggunaan obat yang rasional dalam bentuk komunikasi, informasi dan edukasi yang efektif dan terus-menerus yang diberikan kepada tenaga kesehatan dan masyarakat melalui berbagai media ( WHO, 2010). 
Tabel 3. Distribusi frekuensi rasionalitas penggunaan obat responden

\begin{tabular}{|l|l|c|c|}
\hline No & Kategori & Jumlah & Persentase \\
\hline 1 & Rasional & 149 & 77.2 \\
\hline 2 & Tidak Rasional & 44 & 22.8 \\
\hline & Total & 193 & 100 \\
\hline
\end{tabular}

Penggunaan obat dikategorikan tidak rasional jika ada kriteria rasionalitas penggunaan obat yang tidak terpenuhi. Obat dikatakaan rasional bila semua kriteria rasional dapat terpenuhi. Penggunaan obat yang tidak rasional paling banyak disebabkan oleh efek samping obat(15.5\%), lebih jelasnya dapat dilihat pada Tabel 4 Efek samping yang paling umum dialami responden adalah mengantuk. Efek samping seperti itu banyak dirasakan pasien yang menggunakan obat-obat flu. Kejadian polifarmasi paling sering pada pasien dengan keluhan nyeri dan flu, dengan penggunaan dua jenis obat flu atau obat pereda nyeri dalam waktu bersamaan.

Tabel 4. Distribusi status penilaian untuk setiap kriteria rasionalitas

\begin{tabular}{|c|l|c|c|}
\hline NO & \multicolumn{1}{|c|}{ Kriteria } & Status & Persentase (\%) \\
\hline 1 & Ketepatan Pemilihan Obat & Tepat & 100 \\
\hline & & Tidak Tepat & - \\
\hline 2 & Ketepatan Pemilihan Dosis & Tepat & 93.3 \\
\hline & & Tidak Tepat & 6.7 \\
\hline 3 & Efek Samping Obat & Ada & 15.5 \\
\hline & & Tidak Ada & 84.5 \\
\hline 4 & Kontra Indikasi & Ada & - \\
\hline & & Tidak Ada & 100 \\
\hline 5 & Interaksi Obat & Ada & 0 \\
\hline & & Tidak Ada & 100 \\
\hline 6 & Polifarmasi dengan indikasi sama & Ada & 1.6 \\
\hline & & Tidak Ada & 98.4 \\
\hline
\end{tabular}


Sejalan dengan keluhan yang didapati pada penelitian ini, maka pemilihan subkelas farmakologi obat yang digunakan didominasi oleh golongan obat Antipiretik dan Analgetik (obat demam dan penghilang nyeri), lalu diikuti dengan golongan obat flu, batuk pilek, batuk dan golongan obat lainya seperti vitamin. hasil ini sejalan dengan beberapa penelitian sebelumnya yang menunjukan kelas yang paling umum digunakan pada pengobatan sendiri adalah golongan antipiretik dan analgetik (Lubis, 2014) (Harahap, 2015).

\section{Hubungan Pengetahuan terhadap Rasionalitas Obat}

Hubungan tingkat pengetahuan terhadap rasionalitas penggunaan obat oleh responden. Berdasarkan hasil uji Chi-Square Test antara tingkat pengetahuan dan rasionalitas diperoleh hasil dimana nilai $p>$ alpha $(0,05)$ yaitu 0.924 . Nilai ini sangat besar. Hal ini dapat disimpulkan bahwa Tingkat Pengetahuan tidak memiliki pengaruh besar terhadap rasionalitas. Data lebih lengkap dapat dilihat dari Tabel 5. dibawah ini.

Tabel 5. Analisis Chi-Square Test tingkat pengetahuan terhadap rasionalitas penggunaan obat responden

\begin{tabular}{|l|c|c|c|c|}
\hline \multirow{2}{*}{$\begin{array}{c}\text { Tingkat } \\
\text { Pengetahuan }\end{array}$} & \multirow{2}{*}{$\begin{array}{c}\text { Jumlah } \\
\text { Responden }\end{array}$} & \multicolumn{2}{|c|}{ Rasionalitas } & \multirow{2}{*}{ P } \\
\cline { 3 - 4 } & & Rasional & Tidak Rasional & \\
\hline Baik & 83 & 64 & 19 & \multirow{2}{*}{0.924} \\
\hline Sedang & 74 & 58 & 16 & \\
\hline Buruk & 36 & 27 & 9 & \\
\hline
\end{tabular}

Keterbatasan pengetahuan masyarakat tentang obat dan penggunaannya penyebab terjadi keselahan pengobatan dalam swamedikasi (Depkes RI, 2006). Keterbatasan tersebut menyebabkan rentannya masyarakat terhadap informasi komersial obat, sehingga dikhawatirkan penggunaan obat untuk swamedikasilebih banyak karena mengikuti klaim promosi yang memungkinkan terjadinya pengobatan yang tidak rasional jika tidak diimbangi dengan pemberian informasi yang benar (Utaminingrum, Lestari, \& Kusuma, 2015).

\section{KESIMPULAN}

Hasil penelitian menunjukkan tingkat pengetahuan responden yang melakukan swamedikasi di beberapa apotek Kecamatan Lubuk Basung 
tergolong baik (43.0\%). Rasionalitas penggunaan obat secara swamedikasi di beberapa apotek Kecamatan Lubuk Basung 77,2\% tergolong rasional dan 22,8\% tidak rasional $22.8 \%$. Tidak terdapat hubungan antara pengetahuan dengan rasionalitas swamedikasi yang ditunjukkan dengan nilai $p$ value 0.924 .

\section{DAFTAR PUSTAKA}

Badan Pusat Statistik Sumater Barat. Sistem Informasi Rujukan Statistik. Diakses tanggal 23 Oktober dari https://sumbar.bps.go.id/statictable/2015/04/22/196

Departemen Kesehatan Republik Indonesia, 2006. Petunjuk Teknis Pelaksanaan Standar Pelayanan Kefarmasian di Apotik, Jakarta.

Departemen Kesehatan Republik Indonesia, 2008. Materi pelatihan peningkatan pengetahuan dan keterampilan memilih obat bagi tenaga kesehatan. Jakarta: Departemen Kesehatan Republik Indonesia.

Depkes RI. (2011). Modul Penggunaan Obat Rasional. Jakarta: Kementrian Kesehatan RI. Hal. 5-6.

Depkes RI. 2014. Modul Penggunaan Obat Rasional. Departemen KesehatanRepublik Indonesia. Jakarta.

Harahap, N. A. (2015). Tingkat Pengetahuan dan Rasionalitas Swamedikasi di Tiga Apotek Kota Panyabungan. Skripsi. Medan: Fakultas Farmasi Universitas Sumatera Utara.

Hermawati, D. (2012). Pengaruh Edukasi Terhadap Tingkat Pengetahuan dan Rasionalitas Penggunaan Obat Swamedikasi Pengunjung di Dua Apotek Kecamatan Simanggis, Depok. Depok: Departemen Farmasi, Universitas Indonesia.1(1): 10, 60, 61, 68.

Lubis, A.A. (2014). Tingkat Pengetahuan dan Rasionalitas Pasien Swamedikasi Yang Membeli Obat di Apotik Kimia Farma 106 Kota Medan. Medan: Fakultas Farmasi USU. Hal. 32, 39, 44, 58-62.

Peraturan Mentri Kesehatan Nomor 919/MenKes/Per/X/1993 tentang Kriteria Obat yang Dapat Diserahkan Tanpa Resep. Pasal 2.

Riskesdas, 2013. Riset Kesehatan Dasar 2013. Jakarta: Kementrian Kesehatan Republik Indonesia

Swarjana, I. K. (2012). Metodologi Penelitian Kesehatan. Yogyakarta: CV Andi Offset. Hal. 51, 102.

Utaminingrum, Wahyu, Jessy Endra Lestari, and Anjar Mahardian Kusuma. "Pengaruh Faktor-Faktor Sosiodemografi Terhadap Rasionalitas Penggunaan Obat Dalam Pengobatan Sendiri Pada Pasien Program Pengelolaan Penyakit Kronis (Prolanis)." (2015): 285-288.

WHO. 1998. The Role of the Pharmacist in Self-Care and Self-Medication, Netherland: Department of Essencial Drugs and Other Medicines World Health Organization.

World Health Organization. (2010). Rational Use of Medication. http://www.who.int/mediacentre/factsheets/fs338/en/index.html. 